\title{
LÁZS SÁNDOR
}

\section{A kolláció a domonkos és ferences apácáknál}

Szent Margit magyar nyelvü legendájában többször botlunk olyan mondatba, amelyet érteni vélünk, de valójában nem tudjuk pontosan, mit is jelent. Ilyen a következő mondat is, amely a királylány devócióját jellemzi: „Szent kereszt naptól fogva kedég húsvétig ebéd után egy kevéssé megmarad vala az szororokkal, és az után el megyen vala az karban, és áll vala imádságokban nagy sirálmmal mind kollációig" (Margit-legenda, 5v:18-25). ${ }^{1}$ Az idézett szöveg kérdéses helye a kolláció, annak jelentése, formája és tartalma. ${ }^{2}$ A következők azt vizsgálják, mikor és hogyan tartották a kollációt a kolostorokban.

A kifejezés a sivatagi atyák idejére nyúlik vissza. Az ő szokásuk volt, miként azt Szent Jeromos (347-419/420) az Eustochiumhoz szóló levelében leírja, hogy a remeteként élő szerzetesek - 'coenobiták' - délután három óra tájban összegyültek, ,zsoltárokat énekeltek, a Szentírást olvasták szokás szerint. Imádság után valamennyien letelepedtek, és az, akit atyának neveznek, középen állva elkezd tanítani. És míg ő beszél, olyan nagy csönd van, hogy senki sem mer a másikra pillantani, de még csak krákogni sem". ${ }^{3}$ Az atya beszédét kérdések és válaszok követik. Öket, a sivatagi atyákat kereste föl Johannes Cassianus († 430/435) társával, Germanusszal, hogy megtapasztalják életmódjukat. Az ott hallottakból született aztán a Collationes patrum címü gyüjtemény. ${ }^{4}$

${ }^{1}$ A szöveg latin eredetije a magyar legenda kiadói számára ismeretlen; vö. Szent Margit élete, 1510, Bevezetés, P. BALÁzs János, Bp., MTA Nyelvtudományi Intézet, 1990 (Régi Magyar Kódexek, 10), 22. - Hogy az esemény említése nem egyszerüen a magyar legenda szerkesztőjének önkényes betoldása, azt bizonyítja, hogy a tanúvallomások szintén említik a kollációt: „Item dixit, quod: »Dicta virgo Margaretha a festo Sanctae Crucis usque ad pascha post prandium stabat aliquantulum cum sororibus, et postea intrabat chorum et stabat in orationibus suis cum lacrimis usque ad horam collationis ... «" Monumenta Romana Episcopatus Vesprimiensis (= MEV), I, 189. Az adatot M. Nagy Ilonának köszönöm. A magyar legenda Margit csodáinak leírásában is említi a kollációt: „mikoron ez szoror Petronilla volna az kolláción az egyéb szororokkal komplétának előtte, miképpen szokások szerzetösöknek...” (58r:6-9).

${ }^{2}$ A kollációról szóló részleges összefoglalás: MEZEY László, Irodalmi anyanyelvüségünk kezdetei az Árpád-kor végén, Bp., Akadémiai, 1955, 103-104, 79. jegyzet.

${ }^{3}$ Post horam nonam in commune concurritur, Psalmi resonant, Scripturae recitantur ex more. Et completis orationibus, cunctisque residentibus, medius, quem Patrem vocant, incipit disputare. Quo loquente, tantum silentium fit, ut nemo alium respicere, nemo audeat excreare PL. 22, 420.

${ }^{4}$ A sivatagi atyák szokásairól és a kollációról, annak későbbi - még kora középkori - válto- 
A kolláció kora középkori jelentése Nursiai Szent Benedek (480 körül-547) regulájának nyomán formálódott. A bencés szerzetesek kolláción már olyan öszszejövetelt értettek, amelyen Collationes patrumból olvastak föl, ${ }^{5}$ az általában kora esti esemény innen is vette nevét. ${ }^{6}$ A szerzetesek a késő középkorban, de az újkorban is folytatták ezt a tradíciót. ${ }^{7}$

A szerzetesi hagyomány némely rendben - feltehetőleg a kolostor spirituális irányítójának hatására - más, ám szintén a korábbi tradícióban gyökerező irányt is vehetett. A kolláció ekkor a szerzetesközösségnek azt az összegyülését fedte, amelyen a felolvasás mellett teológiai témákról és ünnepekről, kolostori bünökről és erényekről hallgatták meg a lelki vezető intéseit, előadásait, ${ }^{8}$ de kötetlen beszélgetést is jelentett a konvent tagjai és lelki vezetőjük között. ${ }^{9}$ A célja - akár-

zatairól Söveges Dávid előszava nyújt összefoglalást. CAssianus, Johannes, Az egyiptomi szerzetesek tanitása, fordította Simon Árkád, előszó Söveges Dávid, sajtó alá rendezte Somorjai Ádám, I, Pannonhalma-Tihany, Magyar Bencés Kongregáció, 1998; II-III, Pannonhalma-Tihany, Magyar Bencés Kongregáció, 1999. Latin kiadás: CSEL, 13, 17. Wien, 1886, 1888.

${ }^{5}$ Regula Benedicti, caput XLII, „Et ideo omni tempore, sive ieiunii sive prandii, si tempus fuerit prandii, mox surrexerint a cena, sedeant omnes in unum et legat unus Collationes vel Vitas Patrum, aut certe aliud quod aedificet audientes ... si autem ieiunii dies fuerit, dicta Vespera, parvo intervallo mox accedant ad lectionem Collationum, ut diximus; et lectis quattuor aut quinque foliis, vel quantum hora permittit. " (A használt kiadás: Szent Benedek regulája, ed. Söveges Dávid, Pannonhalma, Bencés Kiadó, 1948; a magyar fordítás is Söveges Dávid munkája.) „Azért minden időben, akár böjti, akár kétszeri étkezés van (a következőket rendeljük): ha kétszeri étkezés van, ahogy felkelnek a vacsorától, üljenek le mindnyájan együtt és az egyik olvasson fel a »Beszélgetések«-ből, vagy »Az atyák életé«-ből, vagy valami mást, amin épülhetnek a hallgatók. ... Ha pedig böjti nap van, kis szünetet tartva a Vesperás elmondása után kezdjenek hozzá a »Beszélgetések « olvasásához, amint mondtuk, és olvassanak el négy-öt lapot, vagy amennyit az idő enged.” I. m. 113.

${ }^{6}$ Mezey 1955, i. m. 35 és Frühwald, Wolfgang, Der St. Georgener Prediger, Studien zur Wandlung des Geistlichen Gehaltes, Quellen und Forschungen zur Sprach- und Kulturgeschichte der germanischen Völker, Neue Folge, 9, Berlin, Walter de Gruyter \& co., [1961], 84.

7 Schwarz Katalin, ,, Mert ihon jönn Aßonyotok és kezében új szoknyák”, Források a klarissza rend magyarországi történetéböl, (Metem Könyvek, 39), Bp., 2002.

${ }^{8}$ Meister Eckhart, Die deutschen und lateinischen Werke, Die deutschen Werke, Traktate, V. Hg. Josef Quint, W. Kohlhammer, [Stuttgart/Berlin], [é. n.], V, 312-313. - Quint a jegyzetek között idézi Du Cange szótárából (Glossarium Ad Scriptores Mediae et Infimae Latinitatis, II, 402) a kollációról szóló helyeket, az egyik: Smaragdus in Regula, cap. 42. „Scripturis divini aliis conferentibus interrogantes conferrunt alii congruas responsiones, et sic quae diu latuerant acculta, conferentibus patefiunt perspicua. (Annak, akinek kérdései vannak a szent írásokról, a többiek találó válaszokat adnak, és így azok a kérdések, amelyek régóta megoldatlanok, minden résztvevő számára érthetőek lesznek.)" Smaragdi Abbatis Expositio in Regulam S. Benedicti, ed. Alfons Spannagel, (CCM, 8), Siegburg, 1974, 263. - A másik idézet Du Cange szótárából: „Ipsa quoque Collatio erit vel pro corrigendis vitiis instruendisque moribus, vel pro reliquis causis ad utilitatem coenobii pertinentibus... (A kolláció a hibák javítására szolgál, és útmutatásul a jó erkölcsökhöz, vagy más dolgokra, amelyek a kolostornak hasznára válnak...)” Regula Sancti Isidori, cap. VIII.

9 Maga a szó eredeti jelentése is megengedi használatát ebben az értelemben. Vö. Mezey 1955, i. m. 35, 103, valamint GrundmanN, Herbert, Religiöse Bewegungen im Mittelalter, Untersuchungen 
csak a Collationes felolvasásának - ezeknek a rövid exhortációknak és beszélgetéseknek is a tanítás, a szerzetesi erények elsajátíttatása volt. ${ }^{10}$

A leírásokból mindezidáig a korai középkor gyakorlatát ismertük meg. Úgy tünik föl, hogy a későbbiekben is ez a két kollációs hagyomány élt tovább, nem ritkán keveredve is egymással. Az előzőkből következő fejlemény a 13. században a kollációs prédikáció, ${ }^{11}$ ez a koldulórendek egyetemi tevékenységével függ össze; ${ }^{12}$ ez a sermotípus végső soron a bibliai és teológiai kérdésekről folyó beszélgetés hagyományából nőtte ki magát. ${ }^{13}$ A kolláció egyes szerzetesrendeken belül is variálódott, különbözhetett aszerint, hogy nők vagy férfiak tartották, de befolyásolta az is, hogy milyen erős egyéniség volt a lelki vezetö, de az is, hogy diákoknak, egyetemi környezetben tartották-e.

A következőkben a domonkos nővérek 13. és 16. század közötti kollációtartási szokásait vizsgáljuk meg a domonkos források alapján, majd néhány következtést

über die geschichtlichen Zusammenhänge zwischen der Ketzerei, den Bettelorden und der religiösen Frauenbewegung im 12. und 13. Jahrhundert und über die geschichtlichen Grundlagen der Deutschen Mystik (Historische Studien, 267), Berlin, Ebering, 1935, 463 skk.

${ }^{10}$ „Cum sit, inquit, utilis ad instruendum lectio, adhibita tamen collatione maiorem intelligentiam, praebet. Melius est enim conferre, quam legere. Collatio autem docibilitatem facit. Nam propositis interrogantibus cunctatio rerum excluditur, et saepe obiectionibus latens veritas approbantur. Quod enim obscurum, aut dubium est, conferendo cito perspicitur." HisPaLENSIs, Isidorus, De summo bono, Lib. III, cap. 15.

${ }^{11}$ A két beszédtípus közötti különbséget MeErsseman, Gilles Gérard, (Les Frères prêcheurs et le mouvement dévot en Flandre au XIIIe siècle = Archivum Fratrum Praedicatorum, 18 [1948], 80-93) így jellemezte: „Aux quatre fêtes de la Vièrge on prêchait, non seulement le matin (sermo) pendant la grand'messe, mais aussi le soir (collatio), pendant la réunion da le congregation" - Idézi: Mezey 1955, i. m. 103. - A későbbiekben Iordanus de Saxonia (1185/90-1237) utasítására nemcsak világiaknak ismételték meg a reggeli prédikációt, hanem a domonkos szerzeteseknek is, akik nem tudtak részt venni a misén; a kolláció így elveszítette beszélgető jellegét, a két sermo ebben az esetben nem különbözött jelentösen. KodA, Yoshiki, Mystische Lebenslehre zwischen Kloster und Stadt: Meister Eckharts »Reden der Unterweisung « und die spätmittelalterliche Lebenswirklichkeit = Mittelalterliche Literatur im Lebenszusammenhang. Ergebnisse des Troisieme Cycle Romand 1994 (Scrinium Friburgense, 8), Hg. von Eckart Conrad Lutz, Freiburg, 1997, 244.

12 Davy, Marie-Madeleine, Les sermons universitaires parisiens de 1230-1231, Contribution à l'histoire de la prédication médiévale, Paris, 1931, 27; HAmesse, Jacquline, "Collatio» et «reportatio», Deux vocables specifiques de la vie intellectuelle au moyen âge = Terminologie de la vie intellectuelle au moyen âge, (Etudes sur le vocabulaire intellectuel du moyen âge, 1), ed. Olga Weijers, Turnhout, 1988, 79. - A kolláció beépült az oktatásba, ekkor rövid egyetemi beszédeket jelentett, amelyeket a teológia magiszterei az egyetemi oktatás során adtak elő. Szent Bonaventurának három, a párizsi egyetemen előadott beszédsorozata maradt ránk: Collationes de decem praeceptis (A Tízparancsolatról tartott beszédek, 1267-ből), Collationes de septem donis (Előadások a Szentlélek hét ajándékáról; 1268) valamint Collationes in Hexaemeron (23 előadás a teremtésről; 1273). Ugyancsak fontosak ebben a müfajban Ioannes Duns Scotus (1266 körül-1308) munkái: Collationes Oxonienses és a Collationes Parisienses. Duns Scotus beszédei az iskolai gyakorlatot tükrözik, míg Bonaventura sermoi inkább prédikációs jellegủek (HAMEsSE 1988, i. m. 82).

${ }^{13}$ Koda 1997, i. m. 243. skk. 
vonunk le a megmaradt magyar nyelvemlékek segítségével; ez a klarissza apácák egyik 16. századi kódexét érinti. A domonkos nővérek kollációs szokásait Humbertus de Romanis (1190/1200-1277) konstitúciója határozta meg, a ferences növérekét nem ismerjük ilyen részletességgel.

A magyar Margit-legendából vett idézet önmagát magyarázza. Az ott elmondottak szerint Margit az ebéd után a kolostortemplom nyugati felében elhelyezett kórusában folytatott magányos lelkigyakorlatot „Szent kereszt naptól fogva ... húsvétig". Ez a periódus a nyugati egyházban és a domonkosok konstitúciójában elöírt böjti és egyben bünbánati időszak volt. ${ }^{14} \mathrm{~A}$ mondat második fele a böjtre vonatkozó elóírásból fejthető tovább. A domonkos nővérek - de a szerzetesek is - a konstitúció utasításának megfelelően ebben a böjti időszakban közös felolvasást tartottak: „Tempore ieiunii hora competenti sacristissa signum ad collationem faciat. Postea refectoraria cimbalum pulset. Deinde sororibus venientibus in refectorium ad signum illius, que preest, legat lectrix premisso iube domine et sequatur benedictionem, et sequatur benedictio Noctem quietam etc. Infra lectionem vero poterunt bibere qui voluerint facto signo ab ea, que preest." ${ }^{15}$ Ezek szerint alkalmas időben a sekrestyés, illetve az ebédlős nővér jelzésére a konvent tagjai a refektóriumba vonultak, ahol felolvasást tartottak, miként azt az ebédnél is tették. ${ }^{16}$

A konstitúció leírása több kérdést vet föl. Az egyik a kolláció helye, a másik az ideje. A szövegből világosan kitetszik, hogy a domonkosok - nemcsak a nővérek, hanem a férfiak is - a kollációhoz a refektóriumban ültek le, ${ }^{17}$ későbbi leírásokból az is kitünik, hogy a klarissza nővérek szintén az ebédlőben gyültek össze a kollációra. ${ }^{18}$ Ezt azért kell itt külön megjegyezni, mert a ciszterciek a kollációt

14 „A festo autem sancte crucis vsque ad pascha continuum teneant ieiunium, et nona dicta comendant exceptis diebus dominicis nisi dispensatiue fiat interdum et ex eam." - Constitutiones sororum ordinis predicatorum, capitulum IV, De ieiuniis. - A már többször idézett Bandellus de Castronovo féle kiadást (Milánó, 1505) használtam, ez volt meg a szigeti apácáknál is. A továbbiakban is ezt a kiadást idézem. A Szent keresztnek több ünnepe is volt, azonos néven emlegetik, így bizonytalan a datálás; vö. SzEnTPÉTERY Imre, Oklevéltani naptár, [Bp.], MTA, 1912, 42 ('crucis festum'), 54. Az ünnep Érszegr Géza szerint (Árpád-kori legendák és intelmek, Bp., Szépirodalmi, 1983. vagy 1987?, 223, 11. jegyzet) húsvét előtt harmadik vasárnap volt, míg Szentpétery május 3-ára teszi az ünnepet, amelyet egyébként nemcsak tavasszal, hanem a Szent Kereszt felmagasztalása néven szeptember 14-én is megültek. Esetünkben nem az őszi, hanem a tavaszi időpont a valószínü.

${ }^{15}$ Constitutiones sororum ordinis predicatorum, capitulum VI, De collatione. A férfiakra szintén ez az utasítás vonatkozott.

${ }^{16}$ A böjti időszakban a klarisszák is kollációt tartottak: „Böjteléseknek idején kedig az közönséges kolláció után, egyetemben mindannyian az karba menjenek, holott mindaddig együtt maradjanak, valamig az Confiteort el nem mondják.” - A klarisszák késői, 1627 körül leírt reguláját kiadta Schwarz 2002, i. m. 81-123. A konstitúció latin forrása ismeretlen.

17 A férfiak és nők konstitúciója nem különbözik lényegesen egymástól.

${ }^{18}$ Az 1754-ben írt rendtartás többször emlegeti a kollációt, de annak tartalmáról nem kapunk fölvilágosítást belőle. Kiadása: SchwArz 2002, i. m. 138, 140, 142-43. Egyetlen alkalommal em- 
a kerengő déli folyosóján tartották, ennek megfelelően ott helyezték el a könyvtárszekrényt, a templom falába pedig padokat építettek be. Ennek nemcsak azért van jelentősége, mert felhívja rá a figyelmet, hogy a kolláció az egyes rendekben különféleképpen zajlott, hanem azért is, mert a régészeti kutatások szerint a Nyulak szigetén - de a budai várban is - a domonkosok kolostorát ciszterci építőmesterek ciszterci elöírások szerint építették, ${ }^{19}$ így a Boldogasszony kolostorában a könyvtár, vagy a könyves szekrény - szintén a ciszterci szokásoknak megfelelően - a kollációs folyosónak nevezett részen lehetett. ${ }^{20}$ Az építészeti adottságok ellenére - legalábbis a konstitúció előírása szerint - a kollációt a szigeti domonkos apácák kolostorában már a 13. századtól kezdve egészen az épület elhagyásáig a refektóriumban tartották.

A kolláció szokásos ideje - mint Margit legendájában már láttuk - a böjti időszak volt, ehhez társultak a domonkos liturgia által kijelölt ünnepek vigíliájának böjti estéi. Ezeken a napokon a domonkos nővérek a vesperás elvégzése után közösen a refektóriumba vonultak. Kétségesnek látszik az időpont, hiszen a konstitúció megfelelő órát - 'hora competenti' - említ. Magyarázatot erre - a Humbertusra rendkívül erős hatást gyakorló - Szent Benedeknél találunk. A Regula Benedicti azt írta elő, hogy még világosban mondják el a vesperást, hogy utána az étkezésnél ne kelljen világítani. ${ }^{21} \mathrm{~A}$ kolláció alatt a nővérek vizezett bort ihattak. ${ }^{22}$ Fontos megemlíteni, hogy ez az étkezés viszonylag rövid volt; Szent Benedek 4-5 lap felolvasásának idejét tartotta megfelelő hossznak. ${ }^{23}$ A kollációt a házfönök jelére fejezték be, áldást mondtak, ${ }^{24}$ és a refektóriumból teljes csendben az

lítik, hogy ekkor felolvasást tartottak: „kollációkor pedig, mikor az olvasást el akarja hagyatni, pohárral kétszer nagyon megüti az asztalt.” I. m. 154. A szöveg forrása ismeretlen.

19 H. GYÜRKY Katalin, A domonkos rend középkori kolostorai Budán = Koldulórendi épitészet a középkori Magyarországon, Művészettörténet - müemlékvédelem, 7, [Bp.], Országos Müemlékvédelmi Hivatal, 1994, 121-135.

20 SCHNEIDER, Ambrosius, Der Baubetrieb der Cistercienser, Die cisterciensische Klosteranlage = Die Cistercienser: Geschichte, Geist, Kunst2, Hg. Ambrosius Schneider, Adam Wienand, Wolfgang Bickel, Ernst Coester, Köln, Wienand Verlag, 1977, 69.

${ }^{21}$ „Ab Idibus autem Septembris usque caput Quadragesimae ad nonam semper reficiant. In Quadragessima vero usque in Pascha ad vesperam reficiant. Ipsa tamen Vespera sic agatur, ut lumen lucernae non indigeant reficientes, sed luce adhuc diei omnia consummentur. Sed et omni tempore sive cena sive refectionis hora sic temperetur, ut luce fiant omnia." - Regula Benedicti, cap. XLI. (Szeptember 14-től a negyvennapi böjt kezdetéig mindig délután három órakor étkezzenek. A nagyböjtben pedig egészen Húsvétig estefelé egyenek. A Vesperást magát úgy végezzék, hogy utána az étkezésnél ne legyen szükség mécses-világításra, hanem még napvilágnál végezzenek el mindent. De más időben is, akár a vacsorát, akár az egyszeri étkezés idejét úgy intézzék, hogy minden napvilágnál történjék.)

22 „Infra lectionem vero poterunt bibere qui voluerint facto signo ab ea, que preest.” - Constitutiones sororum ordinis predicatorum, capitulum VI, De collatione.

${ }^{23}$ Vö. 5. jegyzet.

24 „Finita lectione dicat et qui preest. Adiutorium nostrum in nomine Domini.” - Constitutiones sororum ordinis predicatorum, capitulum VI, De collatione. 
imaterembe mentek a kompletórium elmondására. A kolláció az eddigiek szerint tehát a böjti időszakban tartott közösségi felolvasást jelentette.

Hely és idő tisztázása után át kell térnünk a legfontosabb kérdésre, a kolláció tartalmának tárgyalására, azaz arra, hogy mi és milyen módon hangzott el a növérek elött. Humbertus de Romanis, a domonkos rend V. nagymestere a konstitúció magyarázatában Szent Benedek regulájának mintája nyomán: „In collatione vero et in coena debet providere quod legantur libri aliqui bonae aedificationis, et frecuentius historias quae retineri valeant continentes, ut sunt Vitae Patrum, libri Collationum, et similes." ${ }^{25} \mathrm{Ez}$ az utasítás a 13. században feltétlen érvényes volt. Margit és kortársai elméletileg hallgathattak fölolvasást a Collationes patrumból, latinul mindenképpen, de kérdés, hogy rendelkezésükre állt-e magyar fordítás. Valószínúbb, hogy nem. ${ }^{26} \mathrm{~A}$ domonkos apácák tössi kolostorában a 14. században van ugyan nyoma, hogy - nyilván olvasmányaik következményeként - a sivatagi atyák aszkézisére hajlanának a nővérek, ${ }^{27}$ de a magyar Margit-legenda sehol nem mutatja ennek az önmegtartóztató remeteéletnek elemeit, Szent Margit nem kívánja utánozni őket, a tanúvallomások sem emlékeznek meg a Collationes hatásáról, Margit másfajta mártíromságra, másfajta aszkézisre vágyott. ${ }^{28}$

${ }^{25}$ Humbertus de Romanis, Instructiones de officiis ordinis = Opera de vita regulari, ed. Joachim Joseph Berthier, Romae, 1889, II, 300. - Még a szóválasztáson is jól látszik, hogy Humbertus menynyire követte a Szent Benedek-i szerzetesi hagyományt.

${ }^{26}$ Mezey 1955, i. m. 93 leírja, hogy az 1242-es nagykáptalan határozatai szerint tilos volt a testvéreknek a Szentírást, beszédeket, kollációkat vulgáris nyelvre fordítaniuk. Ez a szabály csak később, a 15. században a rendi reformok hatására változott. A Collationes patrum ismeretére a magyar Margit-legenda is tesz utalást: „,hallgatja vala nagy kévánsággal, szeretettel, alkolmas időn Istennek igíjét, prédikációt; szent atyáknak életeket és egyéb szenteknek legendájukat, életüket és példákat" (9v:4-9). Macellus legendájában van a mü címe : Audiebat avide temporibus opportunis verbum praedicationis et patrum collationes, exempla et legendas sanctorum, LV 9. [1]c. Az adatot M. Nagy Ilonának köszönöm.

${ }^{27}$ Elisabeth Stagel (1300 körül-1360 körül), tössi domonkos rendi apáca szerette volna követni a sivatagi atyák példáját: „Disú ... lere der alten veter sante der diener seiner geistlichen tochter, und si nam es in sich und kerte es auf den weg, daz er meinde da mite, daz si nah der alten veter strenger wise iren lip oh mit grosser kestgung soelti ueben." SEuSE, Heinrich, Deutsche Schriften, Hg. Karl Bihlmeyer, Stuttgart, 1907, 107, 1-4. (Reprint: Frankfurt a. M., 1961.) Vö. Williams-KapP, Werner, Nucleus totius perfectionis: Die Altväterspiritualität und der 'Vita' Heinrich Seuses = Festschrift Walter Haug und Burghart Wachinger, Hg. Johannes Janota, Paul Sappler, Frieder Schanze, I, Tübingen, 1992, 407-421.

${ }^{28}$ Szent Jakab történetét hallgatva Margit szeretett volna azonos mártíriumot elszenvedni: „Akarta volna az Úristen, hogy én voltam volna az időben ez velágon, és metéltettem volna ízenként-foltonként az én Uram, Jézusnak szerelméért, úgy hogy az én kénom sok ideig lött volna, és hogy az én kénom végezetin elvágták volna az én fejemet. Ezeket mikoron mondja vala ez szent szűz, igen vígad vala, mert igen kévánja vala az ő vérét kiötteni Jézusnak, az ő jegyesének vére kiöttéséért" (Margit-legenda, 10v:2-14). A legenda e helyének latin forrását a szentté avatási jegyzőkönyv vallomásaiban találjuk meg. „Deus, vellem, quod fuissem tempore illo, et fuissem taiata in petiis pro amore Iesu Christi ita, quod passio mea durasset multum, et quod in fine truncavissent caput meum pro fusione sanguinis Iesu Christi” MEV, I, 273. Ismételtem köszönöm M. Nagy Ilona segítségét. 
A hivatalos forráson - azaz Humbertus konstitúciómagyarázatán - kívül nincs más forrásunk arra, hogy valójában hogyan is zajlott a magyar domonkos apácáknál a kolláció. Mezey László feltételezte, hogy létezett olyan vulgáris nyelven írott szöveg, amelyet a nővérek elött fölolvashattak, ${ }^{29}$ ennek azonban nincs nyoma, sőt létezésüket a kutatás cáfolta is. ${ }^{30}$ Mezey másik lehetőséget is felvetett, méghozzá az élőszóban történő oktatástét, de rögtön visszakozott is, mondván: „Nem képzelhető ugyanis, hogy talán a Nagyböjt idejétől eltekintve akár kolostorokban is ilyen konferencia beszéd naponként elhangzott volna." ${ }^{31}$ Nem tudjuk, hogyan volt. Azt azonban mindenképpen meg kell fontolnunk, hogy napi olvasmányokhoz rengeteg könyvre lett volna szükség, amelyek közül - már a menynyiségük, valamint Margit korához való kötődésük, életének tanúsága miatt is a pusztítások ellenére fennmaradt volna egy-egy példány. Valószínúbb, hogy nem anyanyelven olvastak föl ekkor sem, akárcsak a többi domonkos apácák által lakott kolostorban. ${ }^{32}$

A legenda mindig arról beszél, hogy valamelyik domonkos fráter szóban mond el egy legendát, vagy prédikációt, netán példát - nem a konventnek, hanem Margitnak; ${ }^{33}$ ha létezett volna megfelelö mennyiségü magyar nyelven lejegyzett szöveg, akkor a kivételezést megvető királylány a közösségi élményt kereshette volna, nem csak magának kért volna magyarázatokat, amelyeket egyébként rögtön meg is osztott társaival. ${ }^{34}$ Feltételezhető hát, hogy inkább rögtönzött, vulgáris nyelvü előadások voltak ezek, mintsem lejegyzett anyanyelvü szövegek felol-

${ }^{29}$ Mezey 1955, i. m. 84-93.

${ }^{30}$ KLANICZAY Tibor, A Margit-legendák történetének reviziója = KLANICZAY Tibor, KLANICZAY Gábor, Szent Margit legendái és stigmái, Bp., Argumentum,1994, 60.

${ }^{31}$ Mezey 1955, i. m. 35.

${ }^{32}$ LÁzs Sándor, A Nyulak szigeti domonkos apácák olvasmányainak korszerüsége = „Látjátok feleim..." Magyar nyelvemlékek a kezdetektöl a 16. század elejéig, Az Országos Széchényi Könyvtár kiállitása 2009. október 29 - 2010. február 28., Bp., Országos Széchényi Könyvtár, 2009, 127-128.

33 ,in festivitatibus sanctorum martyrum et aliorum faciebat sibi exponi et legi per aliquem de fratribus predicatoribus, qui serviunt dicto monasterio vitam et passiones eorum" MEV, I, 232. Amire fel kell figyelnünk, hogy nem egyszerủen felolvasásról van szó, hanem magyarázásról is, azaz Dezső fráter latin szöveget olvasott, amelyet aztán magyarázott és lefordított. A Mezey László által feltételezett magyar nyelvü szövegekről kimutatták, hogy azok nem léteztek 1. KLANICZAY 1994, i. m. 60.

34 „Azért ez szent szüz ez feljül megmondott prédikációt hallgatja vala az vasablakon valamely szororral, némikoron kedég az kapitulumházban fráter Desideriustól, avagy egyéb frátertől, annak utána elmegyen vala ez szent szűz az szororokhoz az mívelőházban, és megmondja vala nékik az szenteknek életöket, avagy az napi evangéliumot, és inti vala őket, hogy ők es azonképpen élnének.” (Margit-legenda, 9v:21-10r:9) MEV, I, 254: ,ipsa sancta Margaretha ... faciebat sibi exponi evangelium illud, quod tunc in missa lectum erat, faciebat sibi similiter exponi \{a fratre Desiderio\} vitas sanctorum \{in dominarum capitulo\} et quando nos eramus in domo illa, in qua sorores laborant, ipsa veniebat illuc, et exponebat nobis, sicut expositum erat sibi evangelium et vita sanctorum, sicut melius sciebat, et instruebat nos, quod semper sic faceremus, sicut legebatur in ipso evangelio et in vitis sanctorum." 
vasása. ${ }^{35}$ Megengedhető, hogy a kolostorban az elöírásoknak megfelelően volt ezen időszakban ebédlői felolvasás az ebéd és a kolláció alatt, de ez akkor is latin nyelvü lehetett, amiből a nővérek semmit sem értettek.

Sajnálatosan sötét a 13. századi anyanyelvü irodalmunkról - és ezzel együtt - a domonkos Boldogasszony-kolostor lelki életéről festett kép, Margit királylányon kívül a nővérek nélkülözni voltak kénytelenek a lelki táplálékot, talán nem is vágytak rá. Margit - a többiek megütközését gyakran kiváltva ${ }^{36}$ - maga is hajlott arra, hogy nem törődve a társadalmi elvárásokkal, a hit igazságát keresse, átérezve Krisztus kínjait, maga is szenvedjen, hogy a szegényeken szánakozva maga is szegénnyé legyen, fogadalmát beteljesítse. ${ }^{37}$ Ehhez nyújtott segítséget kiváltságos állapota, az, hogy királylányként a domonkos rend szerzetesei nagyobb figyelmet szenteltek neki, mint társainak, érdeklődését kielégítették.

A későbbi századok kollációs szokásainak magyarázathoz kitérőt kell tennünk. Még Margit századában, 1294 és 1298 között az erfurti domonkos kolostorban Eckhart mester tartott házfőnökként kollációs előadásokat szerzetestársainak. Ezeknek a leirata Das sint die rede, die der vicarius von Türingen, der prior von Erfurt, boruoder Eckhart predigerordens mit solchen kindern hätte, diu in dirre vrägeten vil dinges, dô sie säzen in collationibus mit einander cím alatt fönn is maradt. ${ }^{38} \mathrm{~A}$ rede der underscheidunge címmel is emlegetett szövegek nem egyszerüen csak beszédek, hanem mint a hosszabb cím is mutatja, olyan konverzáció eredményei, ahol a testvérek a kolláción nem csak hallgattak, hanem kérdeztek is - vrägeten vil dinges - Eckhart mestertől. $1{ }^{39}$ A szövegek a kolostori erényekre oktatnak, engedelmességre, a szegénység szeretetére, valamint gyakorlatias út-

${ }^{35}$ Mezey László az Ómagyar Mária-siralom kódexét kollációs kódexnek nevezte, olyannak, amelyet részben Párizsban iskolázott magyar szerzetesek írtak és használtak, és megkísérelte a kódexet a szigeti Boldogasszony-kolostorhoz kötni 1. Mezey László, Leuveni jegyzetek az Ómagyar Mária-siralomról = Irodalomtörténet, 1971, 356-370. Véleményét a későbbi kutatás nem igazolta, sőt részben cáfolta VizKeleti András (,, Világ világa, virágnak virága...”, [Ómagyar Mária-siralom], Bp., Európa Könyvkiadó, 1986).

36 „Mit mívelsz te? Állasz minden napon a te imádságodban, tartván a te orcádat és orrodat a földön, miképpen a disznó. Talán csak nem a földben keresed az Úristent?” (Margit-legenda, 37r:1-5.)

${ }^{37}$ MÁlyusz Elemér, Árpádházi Boldog Margit, A magyar egyházi müveltség problémája = Emlékkönyv Károlyi Árpád születése ünnepére, Bp., Sárkány Nyomda Részvénytársaság, 1933, 341-384.

${ }^{38}$ Meister Eckhart, Die deutschen und lateinischen Werke, Die deutschen Werke, Traktate, Hg. Josef Quint, W. Kohlhammer, [Stuttgart/Berlin], [1963], V. (Reprint 1987), 137-377. [A 23 beszéd 185-311]

39 „Das sint die rede, die der vicarius von Türingen, der prior von Erfurt, boruoder Eckhart predigerordens mit solchen kindern hätte, diu in dirre vrägeten vil dinges, dô sie säzen in collationibus mit einander. (Ezek a beszédek, amelyeket a türingiai vikárius, az erfurti [kolostor] házfönöke, a prédikáló testvérek rendjéből való Eckhart testvér azoknak a [lelki] gyermekeknek tartott, akik sok dolgot kérdeztek tőle, amikor a kollációra összegyültek.)" Magyar kiadása: Útmutató beszédek, válogatta és fordította Bányai Ferenc, Bp., T-Twins, 1993. 
mutatások a szerzetesi életre. A beszédeket a későbbiekben is sokszor másolták, a nürnbergi domonkos apácák 15. századi kézirataiban is feltünnek. ${ }^{40}$

Eckhart Mester anyanyelvü kollációs beszédei elszigeteltnek látszanak, jóllehet a kollációs beszélgetések tartása gyakoribb volt, mint ez az egyetlen megőrzött emlék. Egyrészt nehéz elképzelni, hogy ne kommentálták volna a később eretnekség hírébe is került Eckhart Mester beszédeit különleges eseményként a kortársak és a közeli utókor mint kilengést, ha a kollációs beszélgetés a 13. században magányos jelenség lett volna. Hasonló szóbeli kollációról férfi kolostorokból tudunk, viszont azok a kollációk a stúdium részét képezték, nem kötődtek a böjthöz. ${ }^{41} \mathrm{~A}$ kollációs prédikáció és a konferenciabeszélgetés tartása - amelyre Eckhart Mester példát adott, más lelki tartalommal - folytatódott a későbbi századokban is.

A 15. századból Közös Élet Testvéreinek köréből maradt fönn jelenős kollációs irodalom. Geert Grote (1340 körül-1384), a devotio moderna megindítója a testvérek helyes útra vezetésének egyik fontos eszközét látta a kollációban: ${ }^{42}$ a templomban a prédikációnak ('sermo generalis'), kisebb körben a kollációnak, feddésnek négyszemközt van helye - írta. Az ő elképzeléseit követték aztán a 15. században a Közös Élet Testvérei. Ünnepnapokon a dél körül az első étkezés után ('post prandium') összegyűltek testvérek, és a Szentírásból vett témát tárgyaltak meg. Vasárnaponként és kijelölt ünnepnapokon a kollációt viszont a vacsora után tartották, ezekre az alkalmakra világiakat is megívtak, ezért - ellentétben a szük körü kollációkkal - ilyenkor nem latinul, hanem anyanyelven beszéltek. ${ }^{43} \mathrm{~A}$ Közös Élet Nővéreinek házaiban a kollációkat a gyóntató vezette. Az amersfoorti Szent Agáta házból fenn maradt egy 1445-ben keletkezett anyanyelvü kollációgyüjtemény. Ezt a nővérek akkori gyóntatója Jan Lubberts van Hattem látta el latin nyelvủ megjegyzésekkel, amelyek szinte „rendezői utasításnak” hatnak. ${ }^{44}$

40 Közösségi kódexben: Nürnberg, Stadtbibliothek, Cent. VI, 55:126r-182v; imakönyvben: Nürnberg, Stadtbibliothek, Cent. VII, 38:233r-236v; Cent VII, 62:103r-113v. SchneIDER, Karin, Die Handschriften der Stadtbibliothek Nürnberg, Band I, Die deutschen mittelalterlichen Handschriften, Beschreibung der Buchschmucks Heinz Zirnbauer, Wiesbaden, Otto Harassowitz, 1965.

${ }^{41}$ KodA 1997, i. m. 243-249. Ez a kolláció nem azonos az apácakolostorokban tartottakkal, hetente egyszer - szombaton vagy vasárnap - gyültek össze megülésére, a kolostor házfőnöke, vagy az a szerzetes - többnyire a lektor - vezette, akit megbíztak tartásával.

$42, \ldots$..devoti quidam apte sumpserunt quedam generalia dicta mea in predicacione mea, que tamen eis in collacione sic universaliter expressa, non sustinuerunt, quasi tunc essent particulariata, quia persone particulari dicta, licet eque generaliter." - Gerardi Magni Epistolae, ed. Willelmus Mulder, Antwerpen 1933, (Tekstuitgaven van OGE, 3), Nr. 61, 227. Az idézet Grote Wilhelm Oude Scutéhoz írott leveléböl származik.

${ }^{43}$ Anton G. WeILER, Volgens de norm van de vroge kerk, De geschiedenis van de huizen van de broeders van het Gemene leven in Nederland (Middeleeuwse Studies 13), Nijmengen, 1997, 26-54, 220-222.

44 Thomas Kock, Zwischen Predigt und Meditation, Die Kollationalia des Dirc van Herxen = Predigt im Kontext, Hg. Volker Mertens, Hans-Jochen Schiewer, Regina D. Schiewer, Wolfram Schneider-Lastin, Berlin, De Gruyter, 2013, 399-420. 
Megjegyzendő még itt, hogy a 'devotio moderna' követői által kialakított kollációs gyüjtemények különböző típusúak voltak. Van, amelyik az egyházi évet követve különféle módon dolgozta föl a témákat, a másik a beszéd fontos pontjait emeli ki vázlatszerüen ('goede punten'), vagy a jó mondásokat ('dicta') emeli ki, a harmadik típus pedig a kolláción megbeszélt szövegeket gyüjti össze. ${ }^{45}$

A Közös Elet Testvéreinek 14. és 15. századi kollációs gyakorlata a női kolostorokban nem talált követőkre, a német domonkos apácákéban semmi esetre sem. Viszonylag sokat tudunk ugyanis a nürnbergi Szent Katalin-kolostor domonkos apácáinak 15. századi kollációiról. Két forrásunk van ehhez. Az egyik az általános érvényü domonkos konstitúció, amely a magyar nővérekre is vonatkozott, a másik pedig a csak egy kolostorra érvényes lista, a nürnbergi domonkos nővérek felolvasásra vonatkozó rendtartása.

A Teutonia domonkos rendtartomány nővéreire a 15 . században változatlanul Humbertus 13. századi előírásai vonatkoztak, a 15-16. század fordulóján Johannes Meyer fordításának köszönhetően már anyanyelven utasította a nővéreket. Eszerint a kolláción olyan könyveket kellett fölolvasni, amelyek elmélyülésre és áhítatra indították a nővéreket, olyan históriákat, amelyeket érdemes megjegyezni, mit például a Vitae patrum, vagy a Collationes patrum, valamint Nagy Szent Gergely Dialogi de vita et miraculis patrum Italicoruma. Nagy ünnepeken - és ez, mint majd látjuk, vonatkozik a kollációra is - aszerint, hogy mi áll a kolostor konventjének rendelkezésére, homíliákat, prédikációkat, szentek passióit és legendáit, és hasonló írásokat kell fölolvasni. ${ }^{46}$

A nürnbergi domonkos nővérek olvasmányjegyzékei, ${ }^{47}$ amelyekből a legtöbb felvilágosítást kapjuk az apácakolostorok középkori felolvasási szokásairól, jelentősen eltérnek Humbertus de Romanis és Johannes Meyer által javasoltaktól. A reform kezdetén összeállított és két éven át bővítgetett lista csak nyolc alkalommal említi a kollációt: szentestére, nagycsütörtök és nagyszombat estéjére,

${ }^{45}$ Kock 2013, i. m. 402

46 A correctrix mensae feladatai közt az Ämterbuchban ezt olvassuk: „Item in der colatio und in dem nacht ymbis sol si versehen, dz man do leß sölche bücher, die do sigint güter anreiczung zu inikeitt und andacht, und allermeist, dz es sigen historien, die man in der gedechtnúß behalten mög, als do ist der heiligen altvetter leben und colationes patrum, dz ist der altvetter red und gütter ler von mangfaltigen tugenden, und das buch dialogorum sancti Gregorii des bopstes, und ander des gleichen büchs. Aber in dem ersten ymbis sol man gemeynlichen leßen die bücher der bibelen und óch zewilen die gúten nuczen búcher der heiligen bewerten lerer, und des gelichen bücher, die der swestern andacht meren weren. Aber zu den großen hochzitten und zu den gefriten tagen ... so mag man lesen omelie, bredigen, passiones und legent der heiligen und anders des gleichen, dz man hett in dem clöster." Stadtarchiv Freiburg/Br., B 1(H), Nr. 108, 133v.

${ }^{47}$ Két jegyzékkel rendelkezünk, az egyik a reform megindulásakor 1429-1431 között készült, a másik pedig az obszervancia kiteljesedésekor folyamatosan bővülve írattatott 1455 és 1461 között. A második jegyzék címe: diß ist der notel, wie man sol zu tisch und zu collacio lesen durch das gancz ior. A két lista kiadása: Mittelalterliche Bibliothekskataloge Deutschlands und der Schweiz, III: Bistum Augsburg, Eichstätt, Bamberg, bearbeitet von Paul Ruf, München 1932. a Továbbiakban: MBK, III/3, 638-650 és 650-670. 
a pünkösdvasárnapot megelőző szombat estére, Gyertyaszentelöre, Mária mennybemenetelének és születésének ünnepe előtt, valamint mindszentek előestéjére ír elő olvasmányokat, ${ }^{48}$ ezek mind anyanyelvü prédikációk és legendák.

Az 1455 és 1461 között összeállított második lista megtartotta a korábban említett kollációs napokat, de kibővült a Mennybemenetel és a Szentháromság-vasárnap ünnepével, ezek vigíliájára írtak elő olvasmányokat, viszont elhagyta a Gyertyaszentelö ünnepének kollációját. Ezek a kollációs napok - néhány elhagyásával és kis bővítéssel - megfelelnek annak a böjti sorozatnak, amelyet a domonkos konstitúció ad: „In toto autem aduentu et quadragessima et ieiuniis quattor temporum, et in vigilia ascencionis, et penthecostes, Sancti Johannis Baptiste, Petri et Pauli, Jacobi, et Beati Dominici, patris nostri, in vigilia Sancti Laurentii, Assumptionis Beate Marie et Bartholomei, et natiuitatis Beate Virginis, Mathei, Simonis et Jude et omnium sanctorum, Andrea apostoliet omnibus sextis feriis quadragessimali vtantur cibo." ${ }^{\prime 49}$ Hiányzik ezek szerint Keresztelő Szent János, Péter és Pál, Jakab, Domonkos, Lőrinc, Bertalan, Máté, Simon Júdás és András vigíliája a kollációs napok közül, míg többletként mutatkozik a Szentháromság-vasárnap..$^{50}$

Amit elözetesen megállapíthatunk, az az, hogy a nürnbergi domonkos apácák kolostorában a kollációkon anyanyelven felolvasottak minden esetben az elkövetkező ünnepre való lelki felkészülést, ráhangolódást jelentették. Az is kijelenthető, hogy - már amennyire a kéziratok azonosíthatóak ${ }^{51}$ - a korábbi listában szereplö olvasmányok nem különböztek a későbbiektől, tehát a reform töretlen volt, nem hozott tartami változásokat, legfeljebb a könyvtár bővülésével párhuzamosan kiegészültek az olvasmányok. Hogy lássuk a különbséget az egyes felolvasások között, érdemes idézni az egyik Mária-ünnepre rendelteket. Gyümölcsoltó Boldogasszony vigíliáján a kolláción a fölolvasás a nürnbergi Szent Katalin-kolostor ebédlőjében a következőképpen zajlott:

\section{Miasszonyunk, amikor a mi Urunkat foganta, kora este az asztalnál ezt kell olvasni:}

E. II. [jelzetü] könyv, prédikáció a mi kedves Asszonyunkról, a LXXXXVI. lapon. M. I. [jelzetü] könyv, az angyali üdvözletröl, a LXXIIII. lapon.

D. I [jelzetü] könyv, prédikáció a mi kedves Asszonyunkról, a CXXVII. lapon.

48 Nem állapítható meg pontosan a tartalmuk, mivel a korábbi olvasmánylista idején még nem volt készen a könyvtár katalógusa, így a könyvek valamelyik jellemzőjük alapján említetnek.

49 Constitutiones sororum ordinis predicatorum, capitulum IV, De ieiuniis. A ieiuniis quattor temporum kifejezés szorul némi magyarázatra, ez a magyar kántorböjt (quatember, quattuor tempora). A kántorböjtöt a nagyböjt első vasárnapja (Invocavit), pünkösd, Exaltatio Crucis (szeptember 14.), advent 3. vasárnapja utáni hét szerdáján, péntekjén és szombatján tartották. Vö. SzENTPÉTERY 1912, i. m. 52 .

50 A Trinitas-vasárnap megtartását a domonkos konstitúció elkészülte után tette kötelezővé XXII. János pápa (1316-1334) 1334-ben, ezért nem szerepelt korábban a domonkosok ünnepei között.

${ }^{51}$ Az első olvasmánylista elkészültekor még nem volt a kolostori könyvtárnak katalógusa, a könyveknek nem volt jelzetük, lapszámozása is csak néhány kódexnek volt. Az olvasáshoz gyakran csak kezdőszavakat adtak meg. 


\section{Kollációra:}

M. VI. [jelzetü] könyv, prédikáció a mi kedves Asszonyunkról, az I. lapon.

A. XIII. [jelzetü] könyv, Cantica canticorum, a II. lapon.

E. XXIII. [jelzetü] könyv, Az 'Ave Mária'a magyarázatával együtt, a CCCCLII. lapon.

N. II. [jelzetü] könyv, prédikáció a Miasszonyunkról, és ez egy kicsiny könyv.

\section{Miasszonyunk napján:}

E. XVII. [jelzetü] könyv, a mise, az episztola és az evangélium a Miasszonyunkról, a XXVIII. lapon.

E. XXII. [jelzetü] könyv, amikor Miasszonyunk a mi Urunkat foganta, a XXIII. lapon.

J. XX. [jelzetü] könyv, a mi kedves Asszonyunk legendája, a CCXVI. lapon.

E. IX. [jelzetü] könyv, prédikáció az Angyali üdvözletröl, a LXV. lapon.

E. XVI. [jelzetü] könyv, prédikáció a mi kedves Asszonyunkról, a CVII. lapon.

E. XXIII. [jelzetü] könyv, az 'Ave Mária'rövid magyarázattal, a CCCX. lapon.

J. X. [jelzetü] könyv, a XII vén a mi kedves Asszonyunkról..$^{52}$

A nővérek az ünnep vigíliáján böjtöltek, délután három óra tájt ebédeltek, majd a vesperás elmondása után következett a kolláció, tehát az ünnep előtti napon tartották meg a böjti étkezés alatti fölolvasást. Ezek az alkalmak azonban nem azonosak a vigíliával, csak azokon a napokon tartottak kollációt, amelyekre böjtöt írtak elő. Ami a kollációk olvasmánylistáján szerepelt, az mind csak ajánlás volt, a 'correctrix mensae' tisztségével megbízott nővér döntése volt, hogy melyik alkalomra mit választ közülük, a felolvasandó szövegek évente variálódtak, hogy a nővérek ne veszítsék el érdeklődésüket.

A tematika az ünnep jellegéből fakadt, amennyire lehetett a müfajok színesítették az olvasmányokat. A Gyümölcsoltó Boldogasszony napja előtt a kolláción lehetőségük volt az M. VI. jelzetü könyvből egy az angyali üdvözletről írt prédikációhoz írott előszót fölolvasni, ${ }^{53}$ az A. XIII-as kódex a Cantica canticorumot és kommen-

${ }^{52}$ MBK, III/3, 667:5-19. „Unser fraw, als sy unsern hern enpfing, frw zu tisch an dem abent sol man lesen: E. II. puch, ein predig von unser lieben frawen, am LXXXXVI. plat. M. I. puch, von dem engelischen gruß, am LXXIIII. plat. D. I. puch, von unser lieben frawen ein predig, am CXXVII. Plat Zu collacio: M. VI. puch, ein predig von unser lieben frawen, am I. plat. A. XIII. puch, cantica conticorum, am II. plat. E. XXIII. puch, das 'Ave Maria' mit der außlegung, am CCCCLII. plat. N. II. puch, ein predig von unser Frawen, und ist ein cleins püchlein.

An dem tag unser frawen: E. XVII. puch, die meß und epistel und ewangelio von unser frawen, am XXVIII. plat. E. XXIII. puch, als unser fraw unsern hern enpfing, am XXIII. plat. J. XX. puch, die legent von unser lieben frawen, am CCXVI. plat. E. IX. puch, ein predig von dem engelischen gruß, am LXV. plat. E. XVI. puch, ein predig von unser lieben frawen, am CVII. plat. E. XXIII. puch, das 'Ave Maria' mit kurczer außlegung, am CCCX. plat. J. X. in dem XII. alten von unser lieben frawen."

${ }^{53}$ Nürnberg Stadtbibliothek, Cent. VI, 59. A kódex első része már a reform előtt készen volt 1. SCHNEIDER 1965, i. m. 198. 
tárját tartalmazta, ${ }^{54}$ az E. XXIII-as kódexből az Ave Mariát és magyarázatát, ${ }^{55}$ az N. II. jelzetüből pedig Mária fogantatásáról szóló prédikációt hallgathattak meg. ${ }^{56}$ Magának az ünnepnapnak az olvasmányai sem tértek el jelentősen. A különbség az volt, hogy az ebédnél a liturgikus szövegeket ismételték meg anyanyelven. Felolvasták a mise fordítását, az episztolát és az evangéliumot, ${ }^{57}$ emellett azonban meghallgatták a fogantatásról szóló legendát (E. XXII, J. XX.), más alkalommal pedig az ünnepről szóló szentbeszédet.

A jegyzék szerint a többi kollációs olvasmányt is az jellemezte, hogy az esti böjtös étkezésen a következő nap ünnepére készítették föl a nürnbergi domonkos nővéreket. Az első és a második olvasmánylista tartalma alig különbözött, a legnagyobb eltérést pünkösd ünnepénél találjuk. Az 1429 és 1431 között összeállított katalógus azt rendeli el, hogy a pünkösdi kollációra olvassák föl a Szentlélekről szóló könyv egy rövid fejezetét arról, hogy miképpen kell viselkedni pünkösd hetében, a szöveg pedig így kezdődik: 'Es spricht sant Gregorius'etc. Ezek után a próféciák könyvéből kell olvasni, mégpedig a 137. lapról, azt a részt, amely így kezdődik: 'So der heilig geist in die sel kumet'. ${ }^{58}$

A későbbi olvasmánylistában a pünkösd előestéjének a kollációjára előírt könyvek között ${ }^{59}$ - a lapszámozás alapján - azonosíthatjuk a korábban 'prophetenbuch'-nak nevezett kéziratot. Ez a különben is sokat használt D. I-es jelzetü kódex, amely mára sajnos elveszett, csak a középkori katalógusból tudjuk, hogy próféciákat is tartalmazott. ${ }^{60}$ A többi kézirat azonosítása lehetetlen, mivel elkal-

${ }^{54}$ Augsburg, Universitätsbibliothek, Oett-Wall. III. 1. 20 8.

${ }_{55}$ A könyv elveszett. A korabeli katalógus leírása szerint Jézusról és Máriáról szóló legendákat tartalmazott, majd egy passiót, a könyv végén pedig egyebek között ismeretlen szerzőtől származó Miatyánk- és Ave Maria-magyarázat volt 1. MBK, III/3, 606:21-31.

${ }^{56}$ Berlin, Staatsbibliothek Preußischer Kulturbesitz, mgo. 137, 47r-67r.

${ }^{57}$ Az E. XVII. jelzetű könyv ma már nincs meg. A középkori katalógus szerint az adventi és a nagyböjti időszak miséinek német fordítását tartalmazta. „Item ein pergamens düns puch in eym conpert; das helt in im die meß in teüczsch in dem advent und fasten und veht sich an 'Ad te levavi animam meam'." MBK, III/3, 606:4-6.

58 „Item an dem heiligen pfingstobent zu kalacyon, so mag man leßen zu dem ersten an des heiligen geistes puch; do steht ein kurz capitel an und ist, wie sich der mensch halten sol die siben tag in der pfingstwochen, und hebt sich an 'Es spricht san Gregorius' etc. Item danach mag man leßen an dem prophetenbuch, do stet auch von dem heiligen geist an und stet an dem CXXXVII. plat und hebt sich an 'So der heilig geist in die sel kumet' etc. (Item ein predig an der Cecilien dunen puch.)" MBK, III/3, 645:9-14.

${ }^{59}$ [Am Pfingstabend] ,Zu der collacion: E. XXIII. puch, von dem heiligen geist, am CLXXV. plat. D. I. puch, so der heilig geist in die sel kumt, am CXXXVII. plat. Mer an dem puch von dem heiling geist, das stet zu hinderst an dem puch; und auch die II sequenczen von dem heiligen geist." MBK, III/3, 660:20-22. („E. XXIII. [jelzetü] könyv, a Szentlélekről a CLXXV. lapon. D. I. [jelzetü] könyv, ahogy a Szentlélek a lélekbe száll, a CXXXVII. lapon. Még több a Szentlélekről ennek a könyvnek végén; és még a Szentlélekről szóló két szekvencia is.”)

${ }^{60}$ [D. I.] „Item ein pergamen puch; das helt in im die propheten und episteln in der vasten und predig und vil guter matery etc.” MBK, III/3, 603:7-8. („Item egy pergamenkönyv; a böjti proféták és episztolák vannak benne, és prédikációk és még sok jó dolog.") 
lódtak. Ami mégis feltünő különbségnek látszik, az két dolog. Az egyik, hogy amíg az első olvasmánylista viselkedési szabályokat is elöír, addig a második ezt elhagyja, jóllehet ez az olvasmány megfelel - miként már láttuk - a kolláció tartalmával szemben támasztott követelménynek, miszerint ezeken az alkalmakon az erkölcsök, a szerzetesi viselkedés elsajátítása, korrigálása az egyik cél. A másik változás egy bővítés, előírták, hogy fel kell olvasni a szentlélekről szóló szekvenciákat is, ${ }^{61}$ magától értetődően ezt is német fordításban. ${ }^{62}$

A többi ünnepen ennél is nagyobb az azonosság a két olvasmánylista között; a továbbiakban a második, az 1455 és 1461 között összeállított listát idézem. Karácsonykor, szenteste kollációján a gyakran használt E. XXIII-as jelzetü kódex legendáját olvasták Jézus születéséről, emellé két prédikációt is javasolt a listát öszszeállító nővér, az egyik Johannes Tauler (1300-1361) karácsonyi beszéde volt. ${ }^{63}$

Nagycsütörtökön nagypéntekre készülve általánosságban írja elő az olvasmányt a lista: „Zu der collation: Von der angst und gefencknüß unsers herren Jhesu Cristi sol man lesen". ${ }^{64}$ Nincs megadva a kódex, amelyből Jézus rettegéséröl és bebörtönzéséröl kellett olvasni ezen a napon, akárcsak a nagyszombat este, amikor Krisztus szenvedéséről és eltemetéséről szólt az olvasmány. ${ }^{65}$

Trinitas-vasárnap előtti estére csupán egyetlen prédikációt olvastak a nővérek, ez a Quicumque vult, azaz a Symbolum Athanasianum magyarázata volt. ${ }^{66}$

A vigíliák kollációin felolvasott szövegek mind a következő nap ünnepének lényegét akarták megragadni. Ha nürnbergi domonkos apácák tartották a böjtöt és a kollációt - a felolvasási listán nem szereplő - egyéb szentek vigíliáján, akkor a ma ismert kéziratok szerint lehetőségük volt legendákat felolvasni, legalább is rendelkeztek szövegekkel ezekre a napokra. ${ }^{67}$

Az olvasmánylista hallgat az egyszerü böjti napok kollációiról, nem ír elő külön olvasmányt. Ha az 1455 és 1461 között összeállított olvasmánylista nem tenne egy eldugott megjegyzést, akkor azt hihetnénk, hogy csak a vigíliákat ülték meg, a többi kollációs napot elhagyták. A correctrix mensae Remete Szent Pál ünnepénél ejti el az utasítást, hogy „Szent Pál legendáját kell felolvasni az Atyák életéből a II. lapon kezdve”. Majd így folytatja: „Továbbá, és ezt a könyvet ol-

${ }^{61}$ Vö. az 58. jegyzettel.

${ }^{62}$ Természetes párhuzamként kínálkozik az, hogy az Érsekújvári Kódexben pünkösd ünnepére írottak között szerepel a két pünkösdi szekvencia magyarul. (72rb:12-73ra:31)

${ }^{63}$ Az E. XV. jelzetü kódex ma már nincs meg, a középkori katalógus leírása: „Item ein predigpuch; das in im helt des Taulers predig, 'Ecce, dies veniunt' hebt es sich an.” MBK, III/3, 605:33-34.

${ }^{64}$ MBK, III/3, 657:35. - Szinte szó szerint azonos az előző olvasmánykatalógus elöírásával 1. MBK, III/3, 643:19-20.

${ }^{65}$, ,Zu der collacion sol man lesen von dem leiden unsers lieben herrenund von der grebnüß.” MBK, III/3, 658:17-18. Ez is szinte szó szerint azonos az előző olvasmánykatalógus elöírásával 1. MBK, III/3, 643:36-37.

${ }^{66}$, ,Zu der collacion: E. XXXIII. puch, ein predig und der 'Quicumque vult' noch dem test, am CXVII. plat.” MBK, III/3, 661:6-7. Nürnberg Stadtbibliothek, Cent. VI, 56:27v-59r. Leírása: SCHNEIDER 1965, i. m. 185.

${ }^{67}$ Der Heiligen Leben címet viselö legendagyüjteménye volt a kolostor könyvtárának. 
vassák föl nekünk a böjtben, hacsak nincs más olvasnivaló kijelölve", ${ }^{68}$ azaz - és ez már az értelmezés -, ha nincs a kollációra szóló speciális tartalmú olvasmány, akkor kell az említett könyvböl fölolvasni, tehát viszonylag gyakran. Az Altveterpuch a Vitas patrum, a konstitúció által a kollációra elóírt böjti olvasmány német címe volt. A kódexet, amely ma is megvan, ${ }^{69}$ a nürnbergi domonkos nővérek másolták a 15. század első felében, azaz a reform bevezetésekor; ${ }^{70}$ ezzel is meg akartak megfelelni a szerzetesi hagyományoknak, azaz a kollációtartásnak, ekkor szerezték be az ott felolvasandó szöveget.

A bemutatottak egyetlen apácakolostor, a nürnbergi Szent Katalin-kolostor kollációs gyakorlatát jellemezték. A gyér adatok közül egy másik - a danzigi (ma Gdańsk) brigittinák 15. századból származó szabályzata - magányos olvasásról számol be. A regulában azt olvassuk, hogy a böjti napokon a vesperás után, amikor kollációt kell tartani, azt nem szabad elmulasztani bármiféle más munka miatt. A kolláción tilos beszélgetni, csendben kell olvasni; ${ }^{71}$ itt tehát nem kijelölt szöveg közös meghallgatásáról van szó.

Azokból a magyar apácakolostorokból, amelyekből a 16. század elejéről nyelv- és irodalmi emlékkel rendelkezünk, egyáltalában nincs hasonló értesülésünk, nem tudjuk, hogy ott miképpen zajlott le a kolláció. A magyar viszonyokat a korábban elemzett domonkos elöírások alapján véljük ismerni. A 13. és 14. század folyamán a magyar apácakolostorokban a hosszú böjti időszak kollációit legföképpen latin nyelvü szövegekkel tudták kielégíteni, de ezek valójában nem

68 „Sant Paulus der erst ainsidel: J. X. puch, die legent von sant Paulus an dem altveterpuch, am II. plat. Item und das puch list man uncz auf die vasten, wenn man nichcz besunders zu lesen hat." MBK, III/3, 666:20-23.

${ }^{69}$ Az olvasmánylistában a jelzetet valószínủleg elírták, mert azon a számon Otto von Passau Die 24 Alten címü munkája van (Nürnberg, Stadtbibliothek, Cent. IV, 44. Leírása: ScHNEIDER 1965, i. m. 59.) A helyes jelezet J. XI., ez valóban a Vitas patrum német fordítását (Leben der Altväter) tartalmazza, és - miként az olvasmányjegyzék a lapszámot is megadja - a II. levélen Remete Szent Pál élete olvasható 1. Nürnberg, Stadtbibliothek, Cent. IV, 18. Leírása: SCHNEIDER 1965, i. m. 18. A kolostor 15. századi kódexkatalógusa is erősíti a nézetemet a tévedésről:

,[J] X. Item ein puch; daran stet die XXIIII alten. Das hat uns die alt Hans Grolatin geschickt, der alten Künczin Imhoff swester.

[J] XI. Item ein puch; das sagt von der heiligen altveter leben, wie sie in der wüst und anderswo und eynod gelebt haben. Das puch haben die swester geschriben.” MBK, III/3, 615:32-36. Vö. még Willing, Antje, Die Bibliothek des Klosters St. Katharina zu Nürnberg: Synoptische Darstellung der Bücherverzechnisse, Band I, Berlin Akademie Verlag, 2012, 510-514.

70 SCHNEIDER 1965, i. m. 18.

71 „Item des vasteldages, na der vesper wan men collacien holden schal, dar schole ok alto male gan ok nycht to vorsumende, vmme jeniges anderen werkes willen.dat sy ok wat id sy, under der collacien. vnder der collacien. scole gy stylle weswen. vnde nycht spreken. mer allene lesen." Tage AHLDÉN, Nonnenspiegel und Mönchvorschriften: Mittelniederdeutsche Lebensregeln der Danziger Birgittinerkonvente: Ein Beitrag zur Geschichte der mittelniederdeutschen Sprache und Kultur auf Grund der Handschrift C 802 Uppsala, Acta Universitatis Gotoburgensis, Göteborg Högskolas Ársskrift, LVIII, 1952,2, Göteborg, 1952, 237-238. 
szolgálták a lelki szükségleteket. Ha nem feltételezzük azt, hogy az elöírt és az emlékekben egyébként emlegetett alkalmakat elhagyták, ${ }^{72}$ akkor Mezey László elgondolása az anyanyelvü prédikációról, a 'konferencia beszédek'-ről nem elvetendő. Jelentősebb kérdés, hogy ezeket a beszélgetéseket kik vezették, a kolostor gyóntatója, vagy voltak-e olyan esetek, amikor egy apácakolostor elöljárói maguk irányították ezeket az eseményeket. Legfeljebb következtetésekkel tudjuk ellensúlyozni a források hiányát.

Az ünnepek előestéjének böjtjére - a megmaradt szövegek alapján - a magyar apácák, mind a klarisszák, mind a domonkosok rendelkezhettek ahhoz hasonló olvasmányokkal, mint amilyeneket a nürnbergi nővérek használtak. Ilyen kézirat volt a domonkos apácáknál a Cornides-, a Horvát- és az Érsekújvári kódex, amelyekből természetesen nemcsak kollációkon olvashattak föl, hanem az ebédnél is ezekből végezték az asztal feletti olvasást.

A ferencesek kéziratai közül a Debreceni és a Nagyszombati kódex vehetö számításba. Ezekben vannak olyan szövegek, amelyek más alkalmakon kívül a kollációs olvasmányként is megfeleltek; említhetőek a később még szóba kerülö rövid prédikációk, a Miatyánk- és az Üdvözlégy-magyarázatok, amelyek meghallgatását a nürnbergi apácák olvasmánylistája is javasolta.

A premontrei nővérek megmaradt anyanyelvü kódexei liturgikus szövegeket őriznek. Az ő Döbrentei-kódexükben, amely zsoltárokat, himnuszokat és perikópákat tartalmaz, megtaláljuk a liturgiában nem gyakran felbukkanó bibliai könyv, az Énekek éneke fordítását is. ${ }^{73}$ A látszólag nem a kódex tartalmához illő szöveg akkor nyeri el értelmét, ha tudjuk, hogy a nürnbergi domonkos apácák is használták asztali és kollációs olvasmányként a Cantica canticorumot és magyarázatát, amely így tehát, ha a liturgiának nem is, a közösségi olvasmányoknak része volt.

Ezek azonban mind feltételezések a megmaradt szövegek használatára vonatkozóan. Egyetlen olyan nyom van, amely bizonyítja, hogy a magyar ferences apácák nemcsak konstitúciójuk szerint voltak kötelesek megtartani a kollációt, ${ }^{74}$ hanem meg is tartották. A pozsonyi klarisszák - és ez már a 17. század elején történt, az akkor a birtokukban lévő - Weszprémi-kódex marginális bejegyzé-

${ }^{72}$ Az egyházi szervezetek institúcióként müködtek, előírásaik betartását szigorúan vigyázták, a kolostorokat rendszeresen vizitálták. Az erősen központosított, szinte katonai fegyelmü domonkos rendben szintén nagyon ügyeltek rá, hogy az egyes kolostorok betartsák a regulát, a konstitúciót, a vizitátorok ezt mindig ellenőrizték is.

${ }^{73}$ A Cantica canticorum fordítása a premontrei eredetü Döbrentei-kódexben (237r:1 - 242r:21), az Ave Mária magyarázata a Nagyszombati-kódexben (351:13-359:11) a nagyheti evangéliumok után olvasható. A német domonkos apácák olvasmányai között az Énekek éneke a húsvét utáni hét csütörtökének kollációjában szerepel (MBK III. 658:41-43), így elhelyezkedése a kódexben megfelel a magyar kódexének is, ahol szintén a húsvéti szövegek között szerepel.

${ }^{74}$ A klarisszák 17. század eleji rendtartása szerint: „Az karban és kapitolomkor, az asztalnál és az kollációkor, minden zörgéstől, nyughatatlanságtól, és mind egyéb munkától és dolgozástól igen csendesek legyenek, ... hanem figyelmetesen hallgassanak, az kapitolomban ugyan az végezésre, intésre, fenyítésre és büntetésre: az karban, az imádságra, az refectóriumba[n] kedig szentleckére, auagy az asztalhoz való olvasásra." Schwarz 2002, i. m. 105. 
se szerint, „mikor elvegzik az imadk bul Nagi Czotortokon C olvazion” (28r). ${ }^{75}$ A csonka szöveg - ha nem idéznénk föl a kolláció végzésének körülményeit értelmezhetetlennek tünne. ${ }^{76}$ A szerzetesek a vesperás elvégzése után a refektóriumba vonultak a kollációra és fölolvasták az aznapra kijelölt szöveget. Itt is erről van szó. Az imádság végeztével nagycsütörtökön Krisztus passióját olvasták föl a kolláción. Párhuzamot is ismerünk hozzá, a nürnbergi domonkos apácák a nagycsütörtöki kolláción tartalmában hasonló szöveget, Krisztus passióját hallgatták: „Von der angst und gefencknüß unsers herren Jhesu Cristi sol man lesen” (MBK, III/3, 657:35). A most említett pozsonyi kolláció jóllehet későbbi, mint tárgyalt korszakunk, mégis nem új fejleményt, hanem a szerzetesi hagyomány folytatását kell látnunk benne.

A 15. és a 16. század fordulójáról származó magyar nyelvü kódexek - még ha jelentős, akár a mostani állomány kétszeresének pusztulásával számolunk is - nem fedezték a nővéreknek az előírások alapján kikövetkeztethető olvasmányszükségletét. Itt vissza kell kanyarodnunk ahhoz a 13. századi gyakorlathoz, amelyről a magyar Margit-legenda révén némi híradást kaptunk, és amelyből - részben Mezey László, részben Klaniczay Tibor már idézett elemzése nyomán ${ }^{77}$ - arra a megállapításra kellett jutnunk, hogy túlnyomó részben rögtönzött szóbeli közlések jellemezhették a lelki gondozást. Valószínű, hogy ezeket a beszédeket legfeljebb alkalmanként jegyezték le. A 15. és 16. század fordulójáról vannak ilyen szövegeink, ezek között kell olyanokat keresnünk, amelyek elhangozhattak, későbbi felhasználásuk pedig akár a kolláció is lehetett.

Az 1519-ből származó, a ferences eredetủ Debreceni kódexben egy ismeretlen szerzetes $^{78}$ írásában maradt fenn egy - sok szempontból összefüggőnek látszó, egységes - gyüjtemény (327-390), amely tartalmában megfelelhet azoknak az igényeknek, amelyeket a böjt bünbánati időszakában az egyszerü hétköznapok kollációi támasztottak. Az összeállítás egyik darabjának sem ismert a forrása. Feltehetően latin előzményeken alapuló magyar prédikációkat, illetve azok vázlatait olvashatjuk az Isten által szeretett lelki tulajdonságokról (436:16-443:15), a búcsúról (443:15-446:2), a számadásról (446:2-449:12), a bủnök előli menekülésről (449:13-458:5), a halálról (458:6-464:15), majd Szent János evangélistáról (464:15-471:17). Ezek az anyanyelvü prédikációvázlatok mindenekelőtt

75 Pusztai István olvasata a sérült marginális a kódex kiadásából 1. Weszprémi-kódex, XVI. század első negyede, A nyelvemlék hasonmása és betühủ átirata bevezetéssel és jegyzetekkel, Közzéteszi Pusztai István, (Régi Magyar Kódexek, 8.) Bp., Magyar Nyelvtudományi Társaság, 1988. [!1989.], 11. - A kódex a 17. század elején a pozsonyi klarisszák birtokában volt, amennyire megállapítható, a bejegyzést az a nővér tette, akinek kézírása több akkor Pozsonyban lévő kéziratban is szerepel.

${ }^{76}$ Korábban magam is rosszul olvastam és értelmeztem a sort.

77 Vö. 2. és 30. jegyzet.

78 Timár Kálmán, Adalékok kódexeink forrásaihoz = Irodalomtörténeti Közlemények, 36 (1926.), 46. - Ez a kódex harmadik kezének írása. 
azért különlegesek, mert hasonlókról nincs máshonnan tudomásunk. ${ }^{79}$ A vázlatok egyébként mindenben tükrözik a korszak prédikációs gyakorlatát, a skolasztikus szabályoknak megfelelően felsorolják a beszéd egyes pontjait, de nem füznek hozzájuk semmi kommentárt, magyarázatot, hiányzik belölük a kifejtett beszéd megszokott narratívája. Minden egyes vázlatpont egyetlen gondolaton vagy idézeten alapszik, a búcsúról szóló beszéd például nem más, mint a megfelelő egyházi törvények felsorolása. Semmi sincs kifejtve, még a magyarázó exemplum sincs leírva, csak utal rá a szerző:

„Másod, ki megbánt embört, hogy meg ne vallja az búcsút, halálos bín. Példa az egy papnak atyafiáról, kit megoldozott vala nagy búcsúval, kárhozék, mert nem vala akaratja, hogy az bínt elhagyja.

Harmad, mikoron meg nem gyónik az búcsúra" (444:3-10). Így folytatódik a felsorolás egészen a hetedik pontig, amely a püspöki fennhatóságról szól:

„ki más pispökség alá menne búcsúra, mert az pispökség alatt való búcsút nem vallja meg, kit az más pispök adott, hanem ha azokért kér áldomást" (444:19445:4). Sem ennek, sem a többi prédikációvázlatnak a végén nem találjuk meg a szokásos zárlatot, a fohászt, amely a beszéd erkölcsi tanulságát a közösségre alkalmazza, és amelyre hallgatóság - esetünkben - a konvent 'ámen'-nel felelt. ${ }^{80}$

Egyszerü felosztásnak látszik a halálról szóló beszéd eleje is, amely alaposabb kifejtést kívánna; abban a formában, amelyben elöttünk áll leginkább memoriternek felel meg.

„Azért tudnonk kell, hogy az halál négyféle oszlást teszön embörnek, annak, ki kárhozik:

Elsőt, mert az halál gonoszoknak lelkét ördögnek adja

Másod, miért az testöket férgeknek adja

Harmadot, mert ez velági jószágát ez velági emböröknek adja

Negyedöt, mert hírét, nevét az szélnek adja, mert mint ez velágból kimúlik, mind az ő jó baráti, felesége, gyermöki és mindönök őróla elfeledköznek" $(458: 14-459: 6){ }^{81}$

A Debreceni kódex most bemutatott prédikációi és prédikációvázlatai kisebb eltérésekkel megfelelnek annak a beszédsorozatnak is, amelyet a 13. században

${ }^{79}$ A kódex leírói helytelenül rövid, gyakorlatias prédikáció-sorozatnak nevezik ezeket a szövegeket 1. Debreceni kódex, 1519, A nyelvemlék hasonmása és betühü átirata, Az előkészítő munkát végezték Abaffy Csilla és Reményi Andrea, bev. Madas Edit, Reményi Andrea (Régi Magyar Kódexek, 21), Bp., Argumentum, Magyar Nyelvtudományi Társaság, 1997, 14.

${ }^{80}$ A beszédvázlatok közül a legkidolgozottabb sermo, a Szent János evangélistáról szóló is nélkülözi ezt a formai elemet. A prédikáció több ponton azonos gondolatsort fogalmaz meg, mint a Könyvecse az szent apostoloknak méltóságokról második fejezete, amely az apostolok helyét taglalja az angyalok és szentek hierarchiájában, azonban a Debreceni kódex e szövegegysége kidolgozottságban meg sem közelíti azt az írást, és ez nem az alkotó stiláris képességeinek tudható be, hanem egyszerüen a szöveg vázlatosságának következménye.

${ }^{81}$ A szöveg tördelése tőlem származik. 
Eckhart Mester tartott a kolláción. Azok a beszédek egyebek mellett a bünök csábításáról, a vezeklésről, az igaz gyónásról szóltak ${ }^{82}$ Ennél talán fontosabb, hogy a prédikációvázlatai igen hasonlítanak a Közös Élet Testvéreinek kollációs beszédeire, mind tartalmukban ${ }^{83}$ mind lejegyzett formájukban. Ebböl azonban nem szabad messzemenő következtetéseket levonni a devotio moderna magyarországi térhódításáról, az ilyen egybeesés a müfaj sajátosságainak is köszönhető. A hasonlóság legfeljebb azt erősíti, hogy valóban kollációs prédikációk vázlataival van dolgunk.

Nehéz megmagyarázni, mire is használhatták a nővérek ezeket a vázlatokat, amelyek valószínúleg magának az előadónak a jegyzetei lehettek. Felolvasásra kevéssé voltak alkalmasak, hiányzik a narratíva. Bár néhol testesebbek a szövegek, a többi feloszlás is hasonlóan rövid. Magányos olvasásra aligha voltak megfelelőek, mert továbbgondolásukhoz komolyabb müveltség kellett volna. Közösségi használatuk akkor lehetett hatásos, ha valaki magyarázta, kibővítette az egyes elemeket. Ilyen felhasználásra a klarissza apácáknál találunk példát.

Az, hogy a magyar klarissza kolostorok elöljárói a lelkivezetó írta szövegek alapján tanítóbeszédeket tartanak társaiknak a 18. század közepén, biztosan szokásban volt. A budai klarisszák rendtartása az apátnő ('abbatissa') feladatai közé sorolja a vasárnapok és az ünnepek előestéjén a kolláció tartását a káptalanteremben. Az ordinárium a rövid exhortációk szövegét is tartalmazza ${ }^{84}$ Ezek olyan konferenciabeszédek voltak, amelyeknek láttuk az előzményeit. Lehetséges, hogy a Debreceni kódex prédikációvázlatai ilyen célból kerültek a klarissza nővérekhez valamelyik ismeretlen lelkigondozójuktól. De hozzá kell tenni, hogy ez az értelmezés pusztán kísérlet arra, hogy értelmezhessük, mit keresnek - az élőszóban egyébként biztosan elhangzott - prédikációk vázlatai a klarisszák kódexében.

Mint ahogy ez a dolgozat is csupán kísérlet arra, hogy megpróbálja kitölteni ismereteink hiányosságait a magyar apácakolostorokban tartott kollációról. Biztos információnk arról van, hogy a 13. század folyamán a Nyulak szigetén lévő domonkos kolostorban a nővérek a rendi elöírásoknak megfelelően megtartották a kollációt, de hogy ott mi, és milyen nyelven hangzott el, hogy az felolvasás vagy szóbeli előadás volt, arról nincs biztos tudásunk. A konstitúció és német példák alapján feltehetőleg latin nyelven olvastak föl a nővéreknek ezeken a böjti délutánokon, de néhány alkalommal élőszóban is elhangozhatott egy rövid prédikáció. A 15. és 16. század fordulóján már anyanyelvü felolvasásokat tarthattak,

${ }^{82}$ Eckhart beszédeinek címei nem sokat árulnak el tartalmukról, így csak a számukat adom meg: 9, 16, 21 ezekben a legkomolyabb a tartalmi megfelelés. Természetes, hogy ennél sokkal több tematikai érintkezés is van, de ez csak annak a jele, hogy a böjti időszakban ezek a témák voltak a fontosak.

${ }^{83}$ Kock 2013, i. m. 416. (44. jegyzet)

${ }^{84}$ Az 1754-ben készült Az Szent Klára szerzetében élö szerzetes szüzek elöljáróinak, avagy abbatisszáinak tisztek szerént való rövid rendtartások elnevezést viselö irat az apátnők segítségére az kollációkra szóló beszédeket állított össze. Közli: SchwARz 2002, i. m. 159-179. 
de ezek tartalmára szintén csak a nürnbergi domonkos nővérek olvasmányaiból következtethetünk. A német nővérek a böjti napokon az Altveterpuchot, azaz a Vitas patrumot olvasták, ünnepek vigíliáján pedig az adott napról szóló olvasmányokkal mélyítették el a liturgikus élményt. A klarissza nővérek kollációs szokásairól ebből az időből ennél is kevesebb a biztos ismeretünk.

\section{LÁZS, SÁNDOR}

\section{Le collationnement auprès des religieuses domincaines et franciscaines}

L'auteur étudie une forme spécifique de l'instruction claustrale : les lectures spirituelles à haute voix. L'étude expose comment les Pères du Désert ont effectué le collationnement : le guide spirituel prononca devant les ermites un rapide sermon que les autres allaient commenter. Cette tradition primitive a continué dans l'ordre de Saint-Benoît, où le terme de collation prenait la signification d'une lecture en communauté : en période de jeun, on a donné en lecture certains passages des Collationes patrum et des Vitae patrum. Dans la constitution des dominicains, on peut facilement repérer les traces de la règle bénédictine. Les freres mendiants - à l'en croire leurs constutitions, les franciscains également - avaient organisé, conformément aux règles de vie, des lectures à haute voix en périodes de jeun : privés de repas, ils n'avaient pris que du vin dilué en eau. Les constitutions indiquent que les religieuses dominicaines et les clarisses étaient également soumises à cette prescription.

D'entre les codex en langue hongroise, seule la légende de Sainte-Marguerite (un texte d'inspiration dominicaine) évoque l'usage du collationnement, par contre, elle ne décrit nullement le déroulement de l'événement. On ignore donc la nature du texte exposé et aussi la langue adoptée pour la lecture. László Mezey a supposé qu'une rapide prédication en langue vernaculaire devait être adressée aux religieuses (comme l'avait fait le Maître Eckhart à Erfurt).

Les religeuses dominicaines de Nüremberg nous ont légué deux registres (15e siècle), qui énumèrent les lectures de collationnement des veilles des fêtes majeures. Tous les textes sont en langue vernaculaire. Ces registres ne disent rien des simples jours de jeun, mais une remarque nous informe que lors des collationnements ayant lieu ces jours-lá la traduction allemande des Vitae patrum avait été au programme.

Certes, les usages caractérisant les cloîtres d'Allemagne de Sud ne prouvent rien par rapport aux établissements en Hongrie, mais celui des dominicains étant un ordre extrêmement centralisé, on peut legitimement supposer des parallélismes. Les religieuses dominicaine du cloître Notre Dame de l'Ile des Lapins - ainsi que les clarisses d'Óbuda - disposaient des textes vernaculaires qui pouvaient faire objet d'une lecture à haute voix aux veilles des grandes fêtes religieuses. Il est probable que la traduction complète des Vitae patrum et des Collationes patrum n'étaient pas encore disponibles. Faute de ces textes, les religieuses ont sans doute écouté en période de Carême des prédications et des avertissements, présentés soit par le spirituel, soit par le directeur du cloître. On peut trouver des indications dans ce sens dans le Codex de Debrecen : les brefs sermons et des esquisses de prédication - peu étudiés jusqu'á nos jours - pouvaient servir à ces fins.

Keywords: 16th century; collatio; Codex-Debreceni; legend of S, Marguerite; erudition; nun's culture; dominicans, franciscans 